\title{
A New Approach to Grazing Management: Using Multi-Herd/Variable Stocking
}

\section{A combination of monitoring, well planned grazing, and drought planning through this new grazing management approach has helped two New Mexico ranches improve livestock productivity, reduce supplemental feed costs, and avoid damaging their rangeland during drought.}

\author{
By Jerry L. Holechek and Dee Galt
}

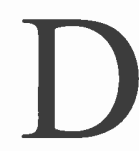
uring the past five years we have had the opportunity to develop and evaluate a new system of grazing management on two different ranches in New Mexico. We have named this grazing system multi-herd/variable stocking. The system we developed incorporates the knowledge gained from stocking rate and grazing system studies in the southwestern United States over the past 50 years.

Variable grazing intensity levels, multiple herds of livestock, and deferment or rest of pastures with low forage production were integrated into a unified system. At any point in time the goal is to have cattle on $75 \%$ of the land while the remaining $25 \%$ of the area receives deferment or rest.

Vegetation type was also considered in developing the plan. Upland pastures with a high component of palatable shrubs are targeted for winter use, while lowland pastures dominated by forbs or cool season grasses are reserved for spring use. After forage production has been determined in November, cattle are shifted away from pastures with the heaviest use and/or lowest forage production to grazing units with the opposite conditions. The goal is to lightly or conservatively graze weak pastures with low forage production while strong pastures with high forage production are targeted for moderate use.

We will provide background information on how our multi-herd/variable stocking grazing plan was derived. Then we will discuss our approach to monitoring, drought planning, and preliminary results from the application of multi-herd/variable stocking on two ranches.

\section{Background Information}

Over the past 100 years, nine basic systems have been developed for grazing livestock on rangelands in the western United States and other parts of the world. These include continuous, season long, deferred rotation, rest rotation, short duration, best pasture, seasonal suitability, high intensity low frequency, and Merrill three herd/four pasture grazing systems. The systems are discussed in detail by Vallentine (7) and Holechek (6).

Each grazing system including continuous and season-long can be effective depending on the type of rangeland involved, the type or types of animals to be grazed, multiple use considerations and goals of the operator. However, no one grazing system has been a panacea for all situations.

The various grazing management studies are consistent in showing that grazing intensity has had more influence on vegetation and livestock productivity than method of rotation $(2,6)$. Research also shows that grazing systems that involve restricting livestock to one half or less of the potential grazing land tend to reduce livestock productivity compared to systems that involve grazing $75 \%$ or more of the land area at any particular time. This reduction occurs because livestock confined to a small area are generally forced to use areas and plants they do not prefer. Forcing livestock to consume plants low in palatability reduces diet quality and forage intake.

The only specialized grazing system to show a consistent advantage over continuous grazing in terms of vegetation response, livestock productivity, 
watershed health and financial returns is the Merrill three herd/four pasture system. The Merrill system differs from other rotation grazing systems in that it involves multiple herds of livestock and at any point in time livestock are spread over $75 \%$ of the potential grazing land. Under the Merrill System each pasture receives four months of nonuse every 12 months. This results in nonuse occurring at a different time of year each cycle. In south Texas where the Merrill system was developed rotating season of nonuse is advantageous because mild winter temperatures characterize the area and rainfall can occur any time during the year. Therefore significant forage growth is possible in any season. However, in other regions with seasonal precipitation and cold winters any benefits of nonuse during the dormant season are doubtful.

In New Mexico, Arizona and western Texas most of the rainfall occurs during the summer from convectional storms. Rainfall across the landscape from these storms is typically uneven. Some parts of a ranch will usually receive much more rainfall than other parts in any given year. Under these conditions changing grazing intensity levels and deferment or rest periods in each pasture according to its specific rainfall, range condition, and plant community is a theoretically sound approach to grazing management. However, it has not been experimentally tested.

\section{The Monitoring Plan}

The monitoring approach developed by Western Range Consultants integrates procedures discussed by Holechek (5) and Allison (1). Precipitation, cattle numbers, grazing periods, forage production and grazing intensity are evaluated annually, for each pasture. Every five years, range condition and trend are evaluated on each pasture using the USDANatural Resources Conservation Service approach. Plant cover is used for condition/trend determinations. Each pasture has one to three key areas generally about $3 / 4$ of a mile from water that are used for monitoring.

The key area-weight estimate procedure developed by Holechek (3) is used to determine grazing capacity for each pasture. Follow-up forage production surveys are made annually in each pasture for autumn stocking rate adjustments. Forage production estimates are also made inside and outside grazing exclosures strategically placed on each ranch. These exclosures vary in size from 5 acres to 40 acres and vary in age from 4 years to 21 years. Grazing intensity surveys are made in all pastures in late spring (May) using procedures of Holechek and Galt (4). Throughout the year stubble heights are routinely used in management decisions for particular pastures.

\section{Drought Planning}

Advance planning for drought is the key to ranching survival in New Mexico. Our grazing approach includes the following components to deal with drought:

1. Monitoring of monthly precipitation across the ranch.

2. Recognizing drought is both unpredictable and a certainty. Therefore a large forage reserve is accumulated in wet years.

3. Maintaining at least one quarter of the herd as readily marketable livestock.

4. Cattle are sold quickly when drought conditions become apparent.

5. Ranch forage resources are inventoried annually.

6. Livestock water supplies are checked constantly.

7. Every effort is made to retain at least one quarter of ranch grazing capacity during the worst drought years.

8. Light grazing levels are assigned to pastures with low forage production and moderate grazing levels to pastures with high forage production.

9. Stubble heights are used to monitor grazing intensity in late spring in all pastures and at other times when appropriate.

\section{Ranch Descriptions}

The two ranches where we have evaluated multiherd/variable stocking are in northern New Mexico and involve shortgrass/pinyon-juniper rangelands. Elevations vary from about 5,500 feet to 7,500 feet above sea level. Average annual precipitation (11-16 inches) comes primarily from rainfall during the months of July, August, and September. Winter 
precipitation is in the form of snow, sleet, or rain. The average frost-free season is about 120 days and extends from about mid-May to mid-September. Rainfall patterns generally favor warm-season vegetation, however, both warm and cool-season plants are present. Primary plant species include pinyon pine, one-seeded juniper, blue grama, western wheatgrass, galleta, threeawn, Indian ricegrass, spike muhly, bottlebrush squirreltail, wolftail, sand dropseed, alkali sacaton, winterfat, fourwing saltbush, and rabbitbrush. Blue grama is the most important forage plant.

\section{Grazing Outcomes}

Since 1994 New Mexico has experienced extended drought. Precipitation for the last 10 years has been $71 \%$ of the long-term average ( 13 inches). The last four years (2000-2003) have all been below average in precipitation with severe drought in 2002 and 2003 (about 52\% of average annual precipitation).

On the two ranches the multi-herd/variable stocking grazing plan has permitted retention of $30-40 \%$ of grazing capacity during the last two years of drought. In contrast, lack of feed has forced most other ranches to completely liquidate their livestock. This difference is explained by more carryover forage and higher plant vigor.

In autumn 2001, 2002, and 2003 Western Range consultants conducted intensive surveys of forage

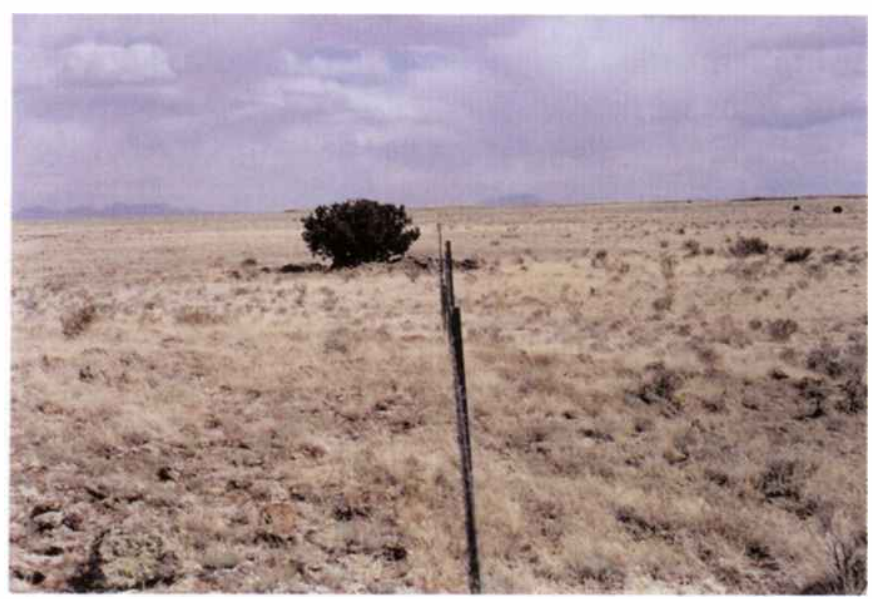

Fig. 1. In November 2002 after three years of severe drought forage production was the same on the grazed area (left) compared to the 20 year grazing excluded area (right). Multi-herd/variable stocking has been used on this area since 1999.

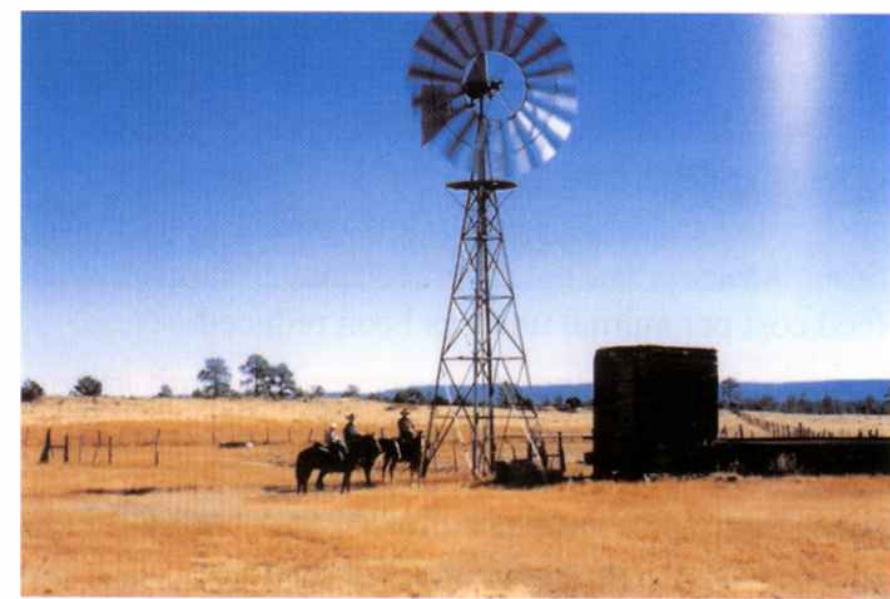

Fig. 2. Vegetation cover around watering points has been maintained under the multi-herd/variable stocking grazing strategy used on this ranch since 1999.

plant health inside and outside the 14 exclosures scattered across the two ranches. Across exclosures and years forage standing crop averaged 165 lbs/acre outside the exclosures compared to 159 lbs/acre inside the exclosures (Figure 1). Perennial grass cover averaged the same outside and inside the exclosures. Plant cover has been well maintained around sensitive areas such as watering points (Figure 2). Plant species composition based on cover was the same outside and inside the exclosures.

Another survey was conducted in autumn 2001 and 2003 to evaluate grass plant survival during the drought. Plants were classified as alive or dead at one yard intervals along two 100 yard transects inside and outside of exclosures. Blue grama was the primary grass species on all sites. Across the 14 exclosures grass plant survival averaged $48 \%$ outside (grazed sites) compared to $46 \%$ inside (ungrazed sites). Based on this information controlled grazing using multi-herd/variable stocking has had no effect on vigor or survival of forage grasses.

In the 1999-2003 period grazing use across two ranches has been conservative. In particular years some pastures received heavy grazing (51-60\% use) but summer deferment coupled with follow-up light grazing has been effective in restoring plant vigor. The multi-herd/variable stocking grazing system is designed to prevent severe grazing (over $60 \%$ use) in any year and prevent consecutive years of heavy grazing. 
Since implementing the multi-herd/variable stocking grazing system in 1999, cattle performance on the two ranches have shown an upward trend. Calf crops and calf weaning weights have increased while cattle death losses have been reduced. Although drought has prevailed, average annual supplemental feed cost per animal unit has been reduced.

\section{Implications}

A combination of monitoring, well planned grazing, and drought planning has allowed two northern New Mexico ranches to maintain a core herd of cattle, improve livestock productivity, reduce supplemental feed costs, and avoid damaging their rangeland during drought. The multi-herd/variable stocking grazing system used on these ranches is considered to be the key to their success. We recognize our evaluations of this system are preliminary and descriptive. We strongly believe more intensive experimental evaluations of this grazing approach are justified.

\footnotetext{
About the Authors: Jerry Holechek is a professor of range science, Department of Animal and Range Sciences, New Mexico State University, Las Cruces, N.M. 88003; and Dee Galt is a private range consultant, 3000 Devandale Drive, Las Cruces, N.M. 88005.
}

This paper was supported by the New Mexico Agricultural Experiment and was part of project 1-5-27417.

\section{References}

1) Allison, D. D., T. T. Baker, J. C. Boren, B. D. Wright, and A. G. Fernald. 2002. Monitoring rangelands in New Mexico: Range, riparian, erosion, water quality, and wildlife. Range Improvement Taskforce Report 53, New Mexico State Univ., Las Cruces, N.M.

2) Heady, H. F. and R. Child. 1994. Rangeland Ecology and Management. Westview Press, San Francisco, Calif.

3) Holechek, J. L. 1988. An approach for setting the stocking rate. Rangelands. 10(1):10-14.

4) Holechek, J. L., and D. Galt. 2000. Grazing intensity guidelines. Rangelands. 22(2):11-14.

5) Holechek, J. L., H. de Souza Gomes, and D. Galt. 1998. Grazing surveys: Problems, experiences and ideas. Rangelands. 20(5):9-11.

6) Holechek, J. L., R. D. Pieper, and C. H. Herbel. 2001. Range Management: Principles and Practices. $4^{\text {th }}$ Edition. Upper Saddle River, N.J.

7) Vallentine, J. F. 1990. Grazing Management. Academic Press, Inc., N.Y. 